\title{
A modified Wipfrag program for determining muckpile fragmentation
}

\author{
by A. Tosun
}

\section{Synopsis}

The size distribution of the muckpile formed as a result of open pit blasting operations has a considerable effect on the efficiency of loading, hauling, and crushing. Various researchers have developed specialized computer software that uses image analysis methods for determining the size distribution of the muckpile. However, these methods have some limitations. One of the most important of these limitations is that the very fine fragments in the muckpile cannot be used in the size distribution calculation. In this study, 18 test blasts in total were carried out in two limestone quarries belonging to Batıçim Corp. in Izmir, Turkey. A new model was developed in order to ensure that very fine fragments are used in the size distribution calculation. The size distributions of the test blasts were calculated by both the Wipfrag computer program and the new model. Correlations were established between the muckpile size distributions determined by both methods and the parameters determining the efficiency of the loader.

Keywords

Muckpile size distribution, blast efficiency, Wipfrag program.

\section{Introduction}

The size distribution of the muckpile formed as a result of open pit blasting operations has a considerable effect on the efficiency of loading, hauling, and crushing. Various researchers have established certain correlations for predicting the efficiency of the operations according to the muckpile size distribution so that production can be carried out economically (Tunstall and Bearman, 1997; Nielsen and Kristiansen, 1996; Workman and Eloranta, 2004; Michaud and Blanchet, 1996; Frimpong, Kabongo, and Davies, 1996; Osanloo and Hekmat, 2005; Molotilov et al., 2010). In these studies, the $50 \%$ passing size $\left(X_{50}\right)$ is generally used. These methods rely on the correct measurement of the size distribution of the muckpile formed by the blast. The most reliable measurement method would be to subject the entire muckpile to a sieve analysis, but this is obviously impracticable. Therefore, computational method based on image analysis have been developed. These include IPACS (Dahlhielm, 1996), Tucips (Havermann and Vogt, 1996), Fragscan (Schleifer and Tessier, 1996), Cias (Downs and Kettunen,
1996), GoldSize (Kleine annd Cameron, 1996), Wipfrag (Maerz, Palangio, and Franklin, 1996), Split Desktop (Kemeny, 1994), PowerSieve (Chung and Noy, 1996), and Fragalyst (Raina et al., 2002). In these methods, the size limits of the fragments forming the material are determined by image analysis on photographs of the muckpile. However, the computer software has some limitations. It does not take into account the third dimension of the muckpile, nor the size distribution of very fine fragments. In particular, the fragment size ranges below 2.5 to $3 \mathrm{~cm}$ cannot be determined, and therefore these cannot be included in the muckpile size distribution. However, the muckpile formed by a bench blast contains a wide range of particle sizes (Tosun et al., 2015).

In this study, a new model was developed in order to ensure that the very fine fragments in the muckpile are included in the size distribution calculation. Eighteen test blasts in total; eight at the Arkavadi limestone quarry and ten at the Upper Aravadi limestone quarry, both belonging to Batıçim Corp. in Izmir,Turkey, were carried out. Initially, the muckpile size distributions from the test blasts $\left(X_{50}\right)$ were determined by the Wipfrag computer program. The size distributions were then calculated for each blast using a new model, which incorporates the very fine fragments. In order to determine which method gives better results, the parameters determining the loading efficiency were used. Many researchers have emphasised that the loading efficiency of the loader depends directly on the muckpile size distribution (Michaud and Blanchet, 1996; Frimpong, Kabongo, and Davies, 1996; Osanloo and Hekmat, 2005; Molotilov et al., 2010). Total pressure values measured in the hydraulic

\footnotetext{
* Dokuz Eylul University, Department of Mining Engineering and Bergama vocational school Bergama-Izmir/Turkey.

(C) The Southern African Institute of Mining and Metallurgy, 2018. ISSN 2225-6253. Paper received Aug. 2017; revised paper received Jun. 2018.
} 


\section{A modified Wipfrag program for determining muckpile fragmentation}

pistons of the loader and the average fuel consumption of the loader were used as the parameters determining the loading efficiency. Correlations were examined between the muckpile size distribution determined both by the Wipfrag computer program and according to the new model with these loader parameters.

\section{Determination of the muckpile size distribution by the Wipfrag program}

The muckpile was divided into sections and photographs were taken of the separated sections. The size ranges of the fragments forming the material were determined by image analysis of the photographs using the Wipfrag program. The size distribution representing the entire muckpile was determined by combining the size distributions obtained from each photograph. For example, nine images in total were obtained by dividing the muckpile of the second test blast in the Arkavadi limestone quarry into sections and each of them was subjected to fragment size analysis using Wipfrag (Figure 1).

A total of 3496 fragments were included in the examination by processing nine images taken from the muckpile, their size distribution graphs were determined, and the average fragment size distribution of the muckpile was obtained by combining the nine graphs into a single graph. The $X_{50}$ value from this graph was calculated as $23.40 \mathrm{~cm}$. The results obtained from the size distribution analyses of this muckpile are given in Tables I and II and Figure 2.

Table III presents the fragment size values $\left(X_{50}\right)$ of the blast tests. The size value of the eighth test blast carried out in the Upper Aravadi limestone quarry could not be determined due to a data storage problem.

\section{Determination of the muckpile size distribution by the new model}

The Wipfrag software calculates the muckpile size distribution according to the number of fragments whose limits can be determined. However, it is not possible to calculate the distribution for fragments in the very fine size range, that is, under $2-3 \mathrm{~cm}$. Even if this were possible, the image would contain millions of fragments. This limitation will result in a biased calculation of the size distribution of the entire muckpile.
A new model was developed in order to ensure that very fine fragments are included in the determination of the size distribution too. Very fine fragments below $2.5-3.0 \mathrm{~cm}$ in each photographic image taken over the muckpile in this model are blacked out, as seen in Figure 3, since their limits cannot be determined. The percentile area of these blacked-
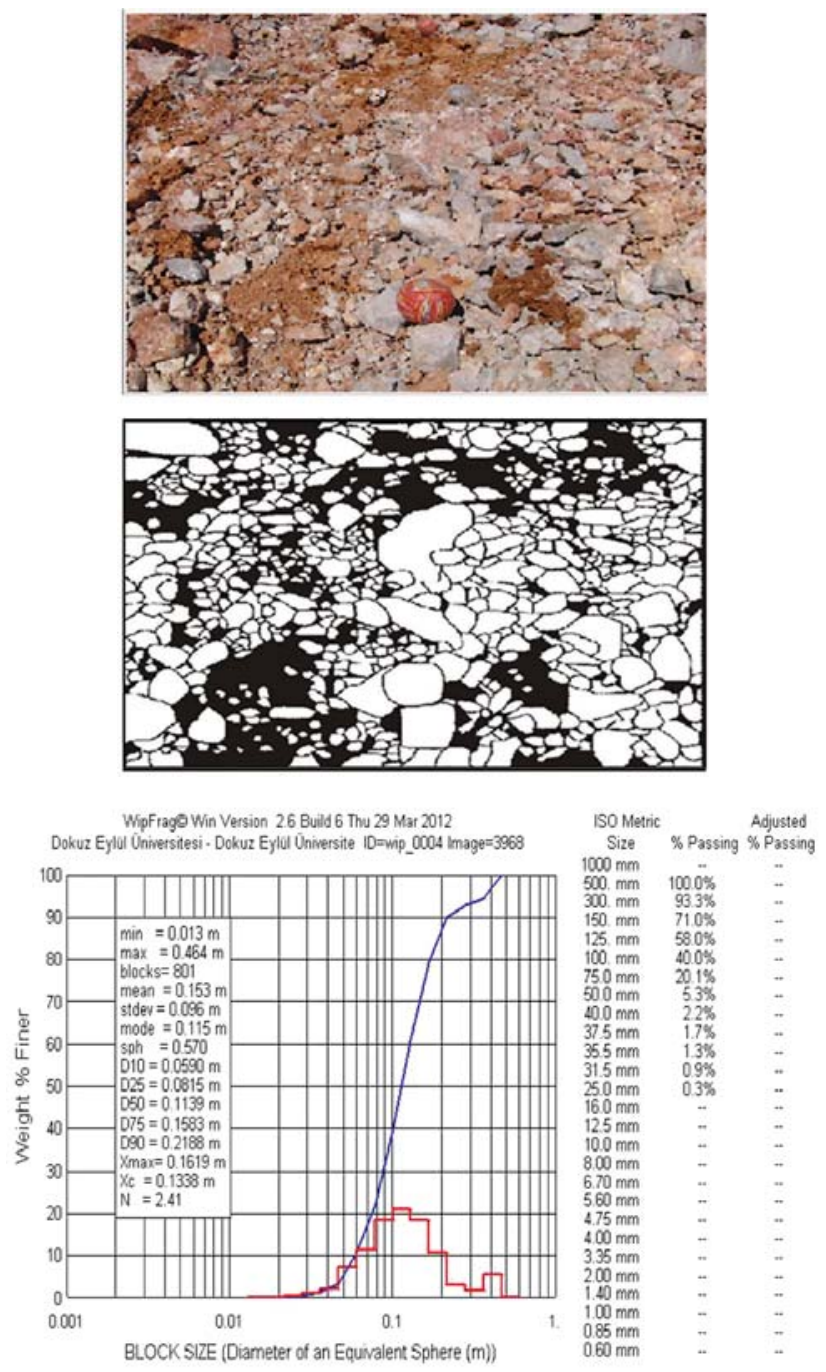

Figure 1-Image analysis phases of a photograph of a portion of the second muckpile blast carried out at the Arkavadi limestone quarry

Table I

The fragment size values derived from a photograph of the second test blast carried out at the Arkavadi limestone quarry

\begin{tabular}{|c|c|c|c|c|}
\hline \multirow[t]{2}{*}{ Photo no. } & \multicolumn{4}{|c|}{ The analysis results provided by the Wipfrag software } \\
\hline & Minimum fragment size (mm.) & Maximum fragment size (mm.) & $X_{50}(\mathrm{~mm})$ & Number of fragment \\
\hline 1 & 13 & 1668 & 417.7 & 379 \\
\hline 2 & 13 & 774 & 192.5 & 609 \\
\hline 3 & 13 & 774 & 297.1 & 343 \\
\hline 4 & 13 & 774 & 140.6 & 670 \\
\hline 5 & 13 & 464 & 113.9 & 801 \\
\hline 6 & 13 & 774 & 299.4 & 300 \\
\hline 7 & 10 & 599 & 373.2 & 156 \\
\hline 8 & 17 & 1668 & 526.2 & 165 \\
\hline 9 & 17 & 2154 & 905.2 & 73 \\
\hline
\end{tabular}




\section{A modified Wipfrag program for determining muckpile fragmentation}

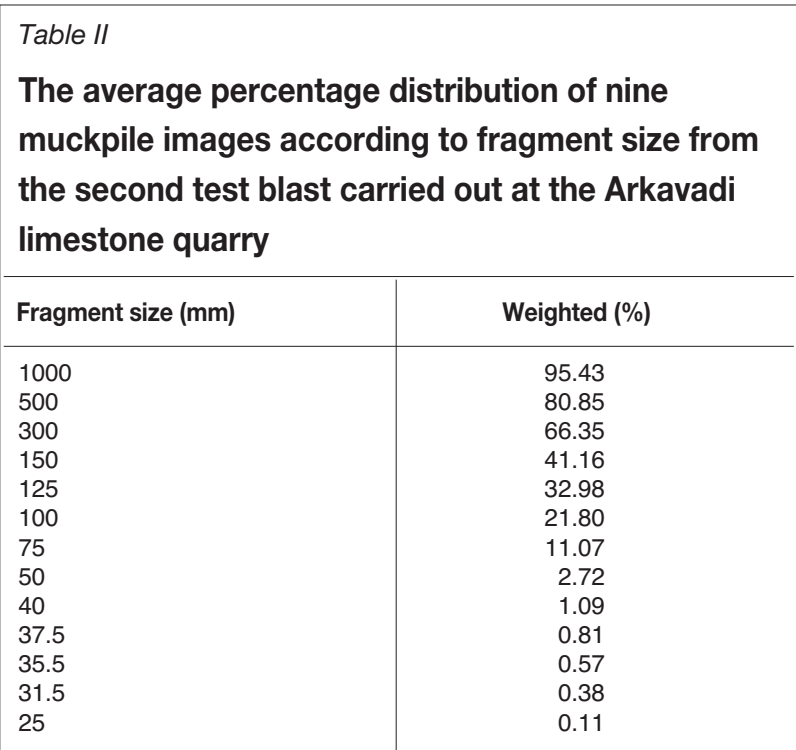

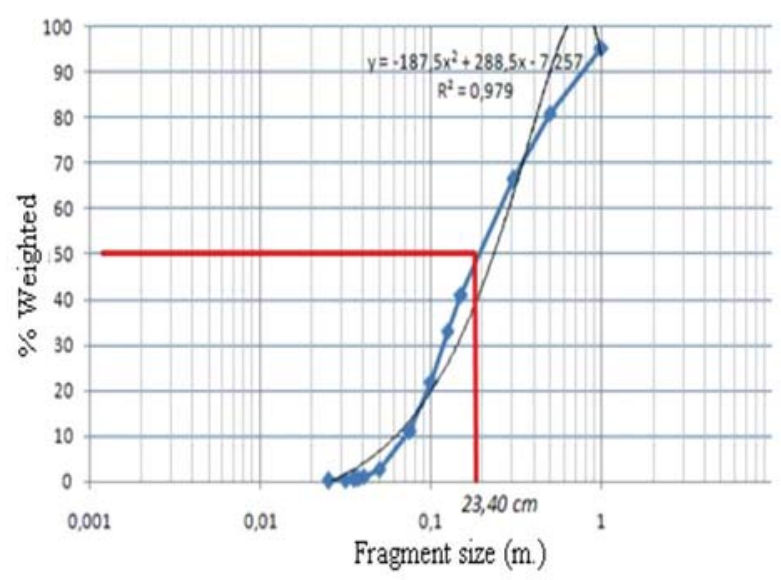

Figure 2-The average fragment size distribution chart from the second test blast carried out at the Arkavadi limestone quarry

out fine fragments was calculated for each image taken over the muckpile. Subtracting the percentile area of blacked-out fine fragments from 100 gives the percentile area of the fragments whose limits can be determined. The weighted average and new size distribution values are then found using the values of average percentile area in the images and the size distribution of the fragments and the fine fragments whose limits can be determined and therefore are used in the calculation of the size distribution (Equation [1]). The size below maximum of very fine fragments that are not used in the size distribution calculation can be seen from the size analysis results determined by Wipfrag. Very fine fragments in the muckpile are not handled according to the number of fragments, but according to the area of the image that they cover.

$$
\mathrm{MW}_{50}=\frac{\left(X_{50} * p\right)+(f * s)}{100}
$$

$\mathrm{MW}_{50}=$ Average fragment size calculated according to the new model $(\mathrm{cm})$

$X_{50}=50 \%$ passing size of the material calculated by the
Table III

Muckpile fragmentation values calculated according to the Wipfrag software $\left(X_{50}\right)$

\begin{tabular}{|l|c|}
\hline Test no. & $\boldsymbol{X}_{\mathbf{5 0}}, \mathbf{c m}$ \\
\hline \multicolumn{2}{|c|}{ Arkavadi limestone quarry } \\
\hline 1 & 21.01 \\
2 & 23.40 \\
3 & 24.62 \\
4 & 22.82 \\
5 & 23.52 \\
6 & 24.78 \\
7 & 21.20 \\
8 & 19.90 \\
\hline & \\
\hline 1 & Upper Aravadi limestone quarry \\
2 & 27.53 \\
3 & 23.58 \\
4 & 27.28 \\
6 & 23.03 \\
7 & 22.93 \\
8 & 24.74 \\
9 & 28.26 \\
\hline
\end{tabular}

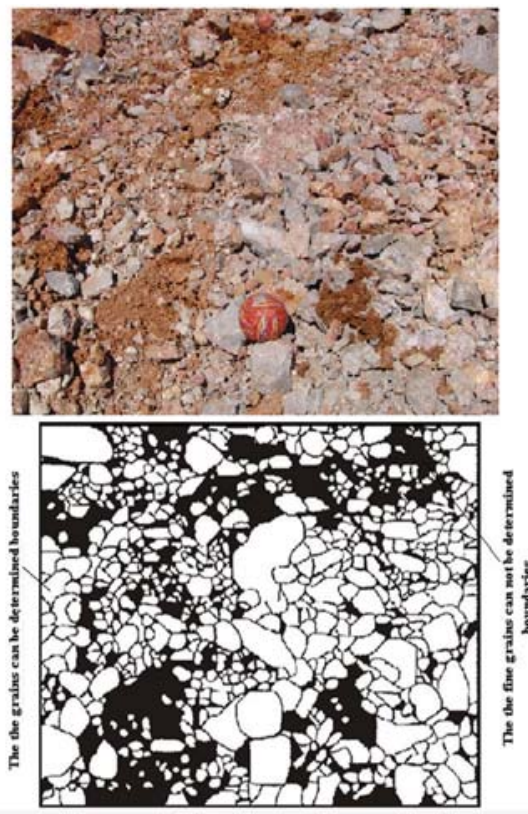

Figure 3-The fine fragments and the fragments whose size can be determined, from a photograph of the second test blast carried out at the Arkavadi limestone quarry

Wipfrag method (cm)

$f \quad=$ Fragment size of upper limit of fines $(\mathrm{cm})$

$p \quad=$ Average area of the fragments whose limits can be determined (\%)

$S \quad=$ Average area of the fragments whose limits cannot be determined (\%)

The Wipfrag size analysis program does not use fragments larger than $1 \mathrm{~m}$ in its calculation of size distribution. Therefore, the real values were found on the 


\section{A modified Wipfrag program for determining muckpile fragmentation}

basis of the fragments used in the size analysis calculation with the Wipfrag size analysis program by extracting the fragments larger than $1 \mathrm{~m}$ in each photograph taken over the muckpile. It was accepted that the $>1 \mathrm{~m}$ fragments were formed as a result of drilling of hard rocks.

For example, nine images were taken over the muckpile in a manner representing the entire muckpile in order to determine the average size distribution of the muckpile formed as a result of the second test blast at the Arkavadi limestone quarry. The percentile areas of fine fragments whose limits cannot be determined and fragments whose limits can be determined in each image were calculated for each image (Table IV).

It was understood from the Wipfrag dimensional analysis program that the fine fragments in this test blast are those smaller than $2 \mathrm{~cm}$. Afterwards, the fragment size value $\left(\mathrm{MW}_{50}\right)$ from which $50 \%$ of the new material is smaller was calculated by means of Equation [1]

$$
\mathrm{MW}_{50}=\frac{(23,4 * 75,83)+2 * 24,17}{100}=18.23 \mathrm{~cm} \text { found }
$$

Table $\mathrm{V}$ presents the fragment size values $\left(\mathrm{MW}_{50}\right)$ of the test blasts according to new model. The $\mathrm{MW}_{50}$ of the eighth test blast carried out in the Upper Aravadi limestone quarry could not be determined due to a data storage problem.

\section{Determination of loader efficiency}

Loading at the Arkavadi limestone quarry is carried out by a PC 450 LC 45 t backhoe hydraulic loader with a bucket capacity of $3 \mathrm{~m}^{3}$, and at the Upper Aravadi limestone quarry by a PC 550 LC $55 \mathrm{t}$ backhoe hydraulic loader with a bucket capacity of $3.6 \mathrm{~m}^{3}$.

To determine the loader efficiency, the oil pressure in the hydraulic pistons of the loader and the average fuel consumption during loading were used. Hydraulic pressure was measured in the front pump, back pump, arm closure, and bucket closure pistons of the loader. The pressures can be monitored instantaneously as numerical values from the monitor in the cabin of the loader. Image processing was used for recording the instantaneous image data on the loader monitor.

\begin{tabular}{|c|c|}
\hline \multicolumn{2}{|c|}{$\begin{array}{l}\text { Table } \mathrm{V} \\
\text { Muckpile fragmentation values calculated } \\
\text { according to the new model }\left(\mathrm{MW}_{50}\right)\end{array}$} \\
\hline Test no. & $\mathrm{MW}_{50}, \mathrm{~cm}$ \\
\hline \multicolumn{2}{|c|}{ Arkavadi limestone quarry } \\
\hline $\begin{array}{l}1 \\
2 \\
3 \\
4 \\
5 \\
6 \\
7 \\
8\end{array}$ & $\begin{array}{l}16.73 \\
18.23 \\
18.19 \\
18.80 \\
16.34 \\
15.15 \\
15.73 \\
16.40\end{array}$ \\
\hline \multicolumn{2}{|c|}{ Upper Aravadi limestone quarry } \\
\hline $\begin{array}{l}1 \\
2 \\
3 \\
4 \\
5 \\
6 \\
7 \\
8 \\
9 \\
10\end{array}$ & $\begin{array}{c}18.60 \\
19.70 \\
19.20 \\
17.35 \\
16.70 \\
17.10 \\
19.10 \\
- \\
18.90 \\
17.80\end{array}$ \\
\hline
\end{tabular}

Electronic (digital) image data can be transformed into numeric data that represents the pressures in the front pump, back pump, arm closure, and bucket closure pistons of the loader by using special software (Tosun et al., 2012). Except for the first test blast at the Arkavadi limestone quarry, the pressures were recorded in a computer environment during completion of the loading of blasted material (Table VI). Hydraulic pressure values during loading of the first test blast at Arkavadi could not be recorded due to certain problems experienced on-site.

The average amount of fuel consumed by the loader while loading the muckpile will vary depending on the size distribution. Fuel consumption values can be monitored from the data tracking monitor on the loader. Before beginning to load the material, the fuel consumption value was reset from

Table IV

The calculating muckpile fragmentation values according to both the Wipfrag software $\left(X_{50}\right)$ and the new model $\left(\mathrm{MW}_{50}\right)$ for the second test blast carried out at the Arkavadi limestone quarry

\begin{tabular}{|c|c|c|c|c|}
\hline Photo no. & $\begin{array}{c}\text { Area of fragments that can } \\
\text { be determined }(\%)\end{array}$ & $\begin{array}{l}\text { Area of fragments that } \\
\text { cannot be } \\
\text { determined }(\%)\end{array}$ & $\begin{array}{l}\text { Muckpile fragmentation } \\
\text { value calculated by } \\
\text { Wipfrag }\left(X_{50}, \mathrm{~cm}\right)\end{array}$ & $\begin{array}{c}\text { Muckpile fragmentation value } \\
\text { calculated according to the } \\
\text { new model }\left(\mathrm{MW}_{50}, \mathrm{~cm}\right)\end{array}$ \\
\hline 1 & 76.05 & 23.95 & \multirow{10}{*}{23.40} & \multirow{10}{*}{18.23} \\
\hline 2 & 73.67 & 26.33 & & \\
\hline 3 & 79.07 & 20.93 & & \\
\hline 4 & 63.96 & 36.04 & & \\
\hline 5 & 57.93 & 42.07 & & \\
\hline 6 & 82.21 & 17.79 & & \\
\hline 7 & 83.31 & 16.69 & & \\
\hline 8 & 83.16 & 16.84 & & \\
\hline 9 & 83.14 & 16.86 & & \\
\hline Average & 75.83 & 24.17 & & \\
\hline
\end{tabular}




\section{A modified Wipfrag program for determining muckpile fragmentation}

the loader data tracking monitor. After the completion of loading, the fuel consumption values were measured as an average for each blast (Table VI). The pressures in the hydraulic pistons of the loader and the amounts of material loaded for each blast are also shown in Table VI.

\section{Evaluation}

The correlations between the muckpile size distribution calculated both by the Wipfrag program and according to the new model with total hydraulic pressure in the loader pistons of the loader and the average fuel consumption during loading were examined (Table VII, Figures 4-11). Since different loaders are used at Arkavadi and Upper Aravadi, the correlations were determined separately for each site.

The muckpile size distribution $\left(X_{50}\right)$ calculated by the Wipfrag program shows poor correlation with the parameters determining loader efficiency, while very meaningful corrrelations are found between the parameters and the size

Table VI

The data used for determining loader efficiency

\begin{tabular}{|c|c|c|c|c|c|c|c|c|}
\hline \multirow[t]{2}{*}{ Test no. } & \multicolumn{4}{|c|}{ Loader hydraulic pressures (kg/cm²) } & \multirow[t]{2}{*}{ Total } & \multirow{2}{*}{$\begin{array}{c}\text { Total number of } \\
\text { data }\end{array}$} & \multirow{2}{*}{$\begin{array}{c}\text { Amount of loaded } \\
\text { material }(\mathrm{t})\end{array}$} & \multirow{2}{*}{$\begin{array}{l}\text { Loader fuel consumption } \\
\qquad(1 / \mathrm{h})\end{array}$} \\
\hline & Front pump & Back pump & Arm closure & Bucket closure & & & & \\
\hline \multicolumn{9}{|c|}{ Arkavadi limestone quarry } \\
\hline 1 & - & - & - & - & - & - & 5512.33 & 27.10 \\
\hline 2 & 192.46 & 185.83 & 12.09 & 14.67 & 405.04 & 138712 & 4156.98 & 37.70 \\
\hline 3 & 181.20 & 183.83 & 5.56 & 23.42 & 394.02 & 13812 & 3721.76 & 33.80 \\
\hline 4 & 189.24 & 193.02 & 9.74 & 8.09 & 400.10 & 12060 & 2447.66 & 34.90 \\
\hline 5 & 172.72 & 177.19 & 7.80 & 10.83 & 368.54 & 91048 & 3167.98 & 27.80 \\
\hline 6 & 161.10 & 160.85 & 4.83 & 9.42 & 336.21 & 146380 & 3814.88 & 23.90 \\
\hline 7 & 165.56 & 169.85 & 7.31 & 10.69 & 353.41 & 85828 & 5987.43 & 25.30 \\
\hline 8 & 169.82 & 176.69 & 5.53 & 8.10 & 360.14 & 59060 & 2272.54 & 30.70 \\
\hline \multicolumn{9}{|c|}{ Upper Aravadi limestone quarry } \\
\hline 1 & 149.39 & 152.43 & 7.21 & 6.44 & 315.47 & 162804 & 2343.94 & 36.20 \\
\hline 2 & 152.27 & 156.58 & 10.00 & 14.90 & 333.70 & 240232 & 2350.10 & 39.30 \\
\hline 3 & 149.11 & 161.90 & 8.13 & 6.72 & 325.90 & 241640 & 7816.74 & 38.70 \\
\hline 4 & 128.13 & 140.73 & 6.69 & 6.53 & 282.09 & 447308 & 4965.16 & 34.70 \\
\hline 5 & 116.60 & 119.19 & 5.08 & 4.26 & 245.12 & 188868 & 995.80 & 29.90 \\
\hline 6 & 137.76 & 139.52 & 7.86 & 5.35 & 290.49 & 149328 & 2084.94 & 35.10 \\
\hline 7 & 147.60 & 151.61 & 7.53 & 15.23 & 321.97 & 85172 & 5861.80 & 37.10 \\
\hline 8 & 146.34 & 150.66 & 8.62 & 6.58 & 312.20 & 146652 & 1673.46 & 35.80 \\
\hline 9 & 147.99 & 160.10 & 7.39 & 8.65 & 324.10 & 197844 & 2653.40 & 38.30 \\
\hline 10 & 140.05 & 148.13 & 6.79 & 5.91 & 300.88 & 234232 & 2305.12 & 35.00 \\
\hline
\end{tabular}

Table VII

The data determining loader efficiency and muckpile fragmentation values calculated according to both the Wipfrag software $\left(X_{50}\right)$ and the new model $\left(M_{50}\right)$

\begin{tabular}{|c|c|c|c|c|c|c|c|c|}
\hline \multirow[t]{2}{*}{ Test no. } & \multicolumn{4}{|c|}{ Loader hydraulic pressures $\left(\mathrm{kg} / \mathrm{cm}^{2}\right)$} & \multirow[t]{2}{*}{ Total } & \multirow{2}{*}{$\begin{array}{c}\text { Loader fuel } \\
\text { consumption } \\
\text { (l/h) }\end{array}$} & \multirow{2}{*}{$\begin{array}{l}\text { Muckpile fragmentation } \\
\text { calculated according to } \\
\text { the Wipfrag }\left(X_{50}, \mathrm{~cm}\right)\end{array}$} & \multirow{2}{*}{$\begin{array}{l}\text { Muckpile fragmentation } \\
\text { calculated according to } \\
\text { the new model }\left(\mathrm{MW}_{50}, \mathrm{~cm}\right)\end{array}$} \\
\hline & Front pump & Back pump & Arm closure & Bucket closure & & & & \\
\hline \multicolumn{9}{|c|}{ Arkavadi limestone quarry } \\
\hline $\begin{array}{l}1 \\
2 \\
3 \\
4 \\
5 \\
6 \\
7 \\
8\end{array}$ & $\begin{array}{c}- \\
192.46 \\
181.20 \\
189.24 \\
172.72 \\
161.10 \\
165.56 \\
169.82\end{array}$ & $\begin{array}{c}- \\
185.83 \\
183.83 \\
193.02 \\
177.19 \\
160.85 \\
169.85 \\
176.69\end{array}$ & $\begin{array}{r}- \\
12.09 \\
5.56 \\
9.74 \\
7.80 \\
4.83 \\
7.31 \\
5.53\end{array}$ & $\begin{array}{r}- \\
14.67 \\
23.42 \\
8.09 \\
10.83 \\
9.42 \\
10.69 \\
8.10\end{array}$ & $\begin{array}{c}- \\
405.04 \\
394.02 \\
400.10 \\
368.54 \\
336.21 \\
353.41 \\
360.14\end{array}$ & $\begin{array}{l}27.10 \\
37.70 \\
33.80 \\
34.90 \\
27.80 \\
23.90 \\
25.30 \\
30.70\end{array}$ & $\begin{array}{l}21.01 \\
23.40 \\
24.62 \\
22.82 \\
23.52 \\
24.78 \\
21.20 \\
19.90\end{array}$ & $\begin{array}{l}16.73 \\
18.23 \\
18.19 \\
18.80 \\
16.34 \\
15.15 \\
15.73 \\
16.40\end{array}$ \\
\hline \multicolumn{9}{|c|}{ Upper Aravadi limestone quarry } \\
\hline $\begin{array}{l}1 \\
2 \\
3 \\
4 \\
5 \\
6 \\
7 \\
8 \\
9 \\
10\end{array}$ & $\begin{array}{l}149.39 \\
152.27 \\
149.11 \\
128.13 \\
116.60 \\
137.76 \\
147.60 \\
146.34 \\
147.99 \\
140.05\end{array}$ & $\begin{array}{l}152.43 \\
156.58 \\
161.90 \\
140.73 \\
119.19 \\
139.52 \\
151.61 \\
150.66 \\
160.10 \\
148.13\end{array}$ & $\begin{array}{r}7.21 \\
10.00 \\
8.13 \\
6.69 \\
5.08 \\
7.86 \\
7.53 \\
8.62 \\
7.39 \\
6.79\end{array}$ & $\begin{array}{r}6.44 \\
14.90 \\
6.72 \\
6.53 \\
4.26 \\
5.35 \\
15.23 \\
6.58 \\
8.65 \\
5.91\end{array}$ & $\begin{array}{l}315.47 \\
333.70 \\
325.90 \\
282.09 \\
245.12 \\
290.49 \\
321.97 \\
312.20 \\
324.10 \\
300.88\end{array}$ & $\begin{array}{l}36.20 \\
39.30 \\
38.70 \\
34.70 \\
29.90 \\
35.10 \\
37.10 \\
35.80 \\
38.30 \\
35.00\end{array}$ & $\begin{array}{c}27.53 \\
23.58 \\
27.28 \\
23.03 \\
22.93 \\
24.74 \\
28.26 \\
- \\
25.02 \\
31.34\end{array}$ & $\begin{array}{c}18.60 \\
19.70 \\
19.20 \\
17.35 \\
16.70 \\
17.10 \\
19.10 \\
- \\
18.90 \\
17.80\end{array}$ \\
\hline
\end{tabular}




\section{A modified Wipfrag program for determining muckpile fragmentation}

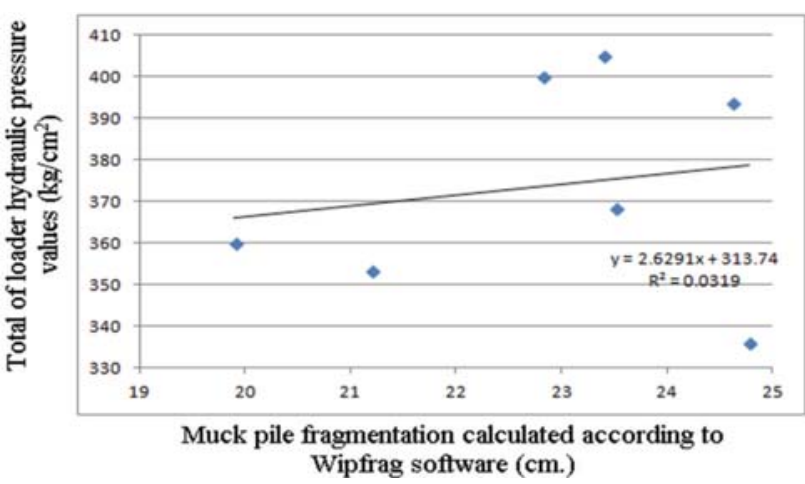

Figure 4-Relationship between total loader hydraulic pressure values and muckpile fragmentation calculated according to Wipfrag $\left(X_{50}\right)$ for the Arkavadi limestone quarry

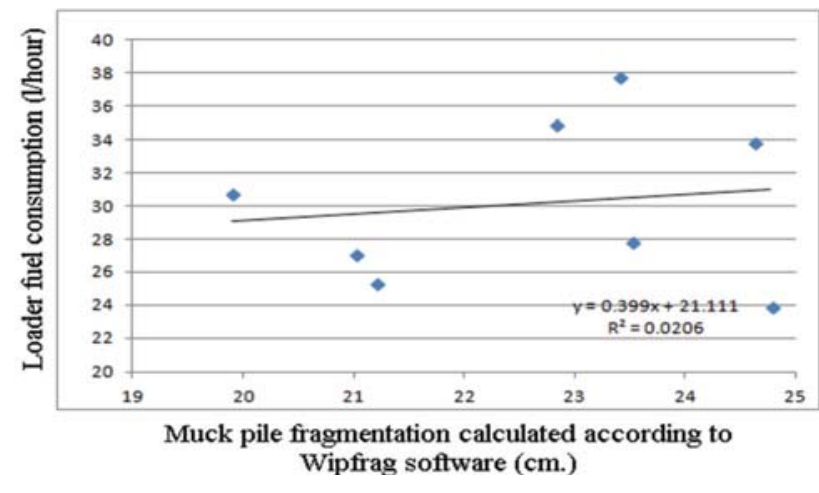

Figure 5-Relationship between loader fuel consumption and muckpile fragmentation calculated according to the Wipfrag software $\left(X_{50}\right)$ for the Arkavadi limestone quarry

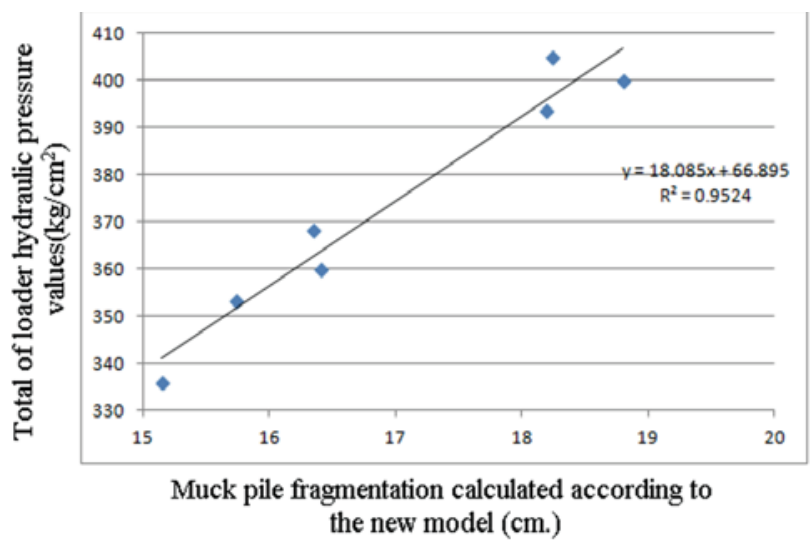

Figure 6-Relationship between total loader hydraulic pressure values and muckpile fragmentation calculated according to the new model $\left(\mathrm{MW}_{50}\right)$ for the Arkavadi limestone quarry

distribution $\left(\mathrm{MW}_{50}\right)$ determined according to the new model, in which the very fine fragments are also evaluated.

Total hydraulic pressure in the pistons of the loader and the average fuel consumption by the loader used in the determination of the loader efficiency according to the muckpile size distribution are the net data where no error occurred. Therefore, it is understood that the new model circumvents certain deficiencies of the Wipfrag computer program used in the determination of the muckpile size distribution.

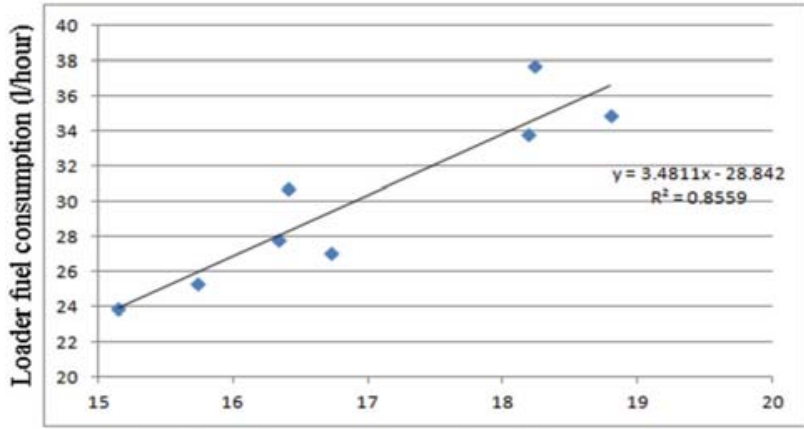

Muck pile fragmentation calculated according to the new model $(\mathrm{cm}$.

Figure 7-Relationship between loader fuel consumption and muckpile fragmentation calculated according to the new model $\left(\mathrm{MW}_{50}\right)$ for the Arkavadi limestone quarry

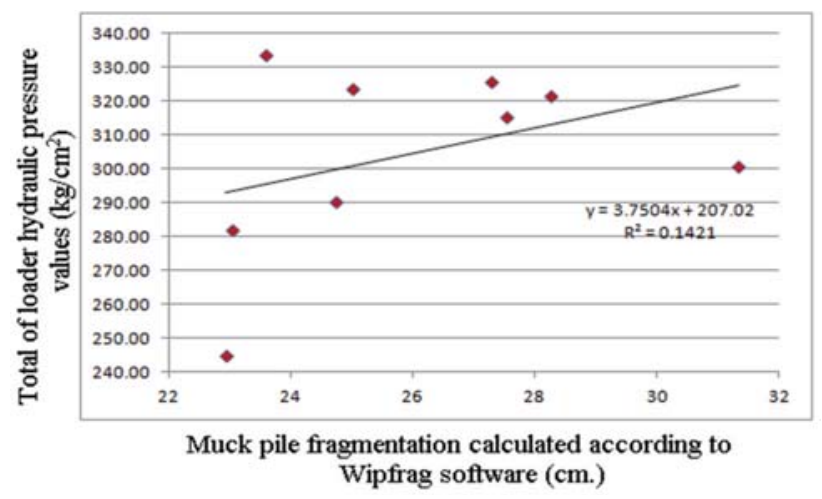

Figure 8-Relationship between total loader hydraulic pressure values and muckpile fragmentation calculated according to the Wipfrag software $\left(X_{50}\right)$ for the Upper Aravadi limestone quarry

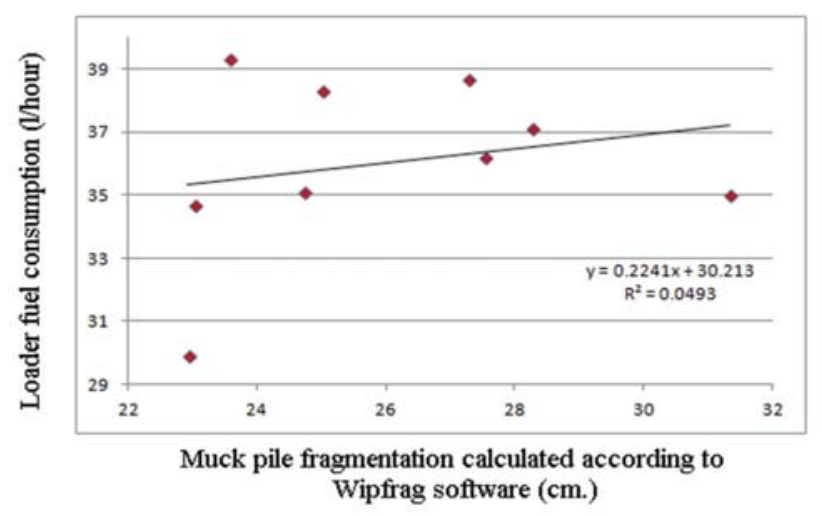

Figure 9-Relationship between loader fuel consumption and muck pile fragmentation calculated according to the Wipfrag software $\left(X_{50}\right)$ for the Upper Aravadi limestone quarry

\section{Conclusion}

In this study, 18 test blasts in total; eight at the Arkavadi limestone quarry and ten at the Upper Aravadi limestone quarry belonging to Batıçim Corp. in Izmir, Turkey, were carried out. Muckpile size distribution values were calculated for each blast using the Wipfrag computer program $\left(X_{50}\right)$ and a new model which also evaluated very fine fragments in the 


\section{A modified Wipfrag program for determining muckpile fragmentation}

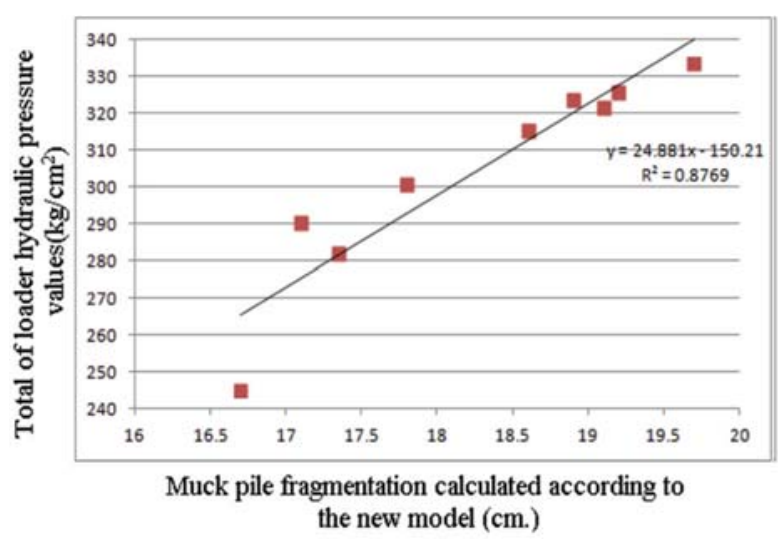

Figure 10-Relationship between total loader hydraulic pressure values and muckpile fragmentation calculated according to the new model $\left(\mathrm{MW}_{50}\right)$ for the Upper Aravadi limestone quarry

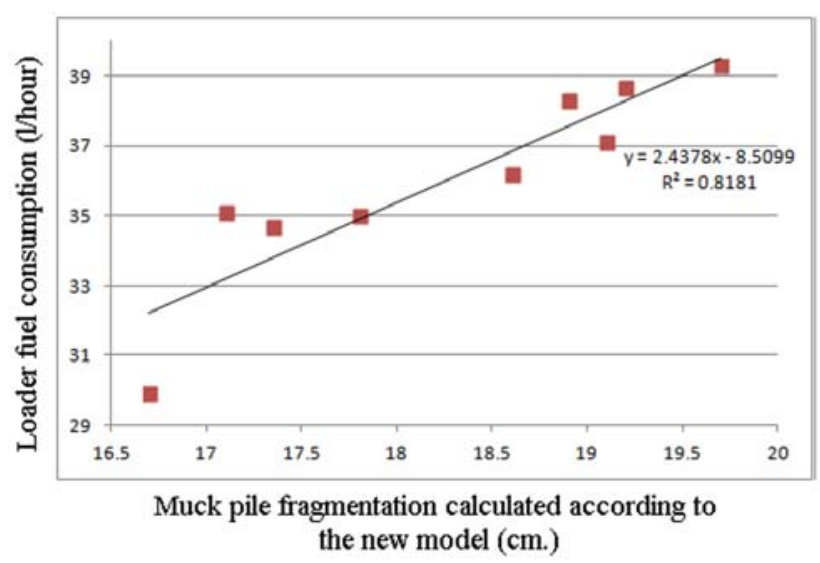

Figure 11-Relationship between loader fuel consumption and muckpile fragmentation calculated according to the new model $\left(\mathrm{MW}_{50}\right)$ for the Upper Aravadi limestone quarry

muckpile. The relationships between the muckpile size distributions calculated by both methods were compared with the total hydraulic pressure values in the hydraulic pistons of the loader and the average fuel consumptions by the loader, which are the parameters determining the loader efficiency, were examined. No relationship whatsoever was determined between the loader efficiency and the muckpile size distribution $\left(X_{50}\right)$ by the Wipfrag computer program, but very meaningful relationships were seen between the parameters and the size distribution according to the new model.

\section{Acknowledgments}

I wish to thank the Scientific and Technological Research Council of Turkey (TUBITAK) for providing funding for this research project, and Western Anatolia Cement Factory for their help during field studies.

\section{References}

Chung, S.H. and Noy, M.J. 1996. Experience in fragmentation control. Measurement of Blast Fragmentation: Proceedings of the Fragblast-5 Workshop on Measurement of Blast Fragmentation, Montreal, Quebec, Canada, 23-24 August 1996. Franklin, J.A. and Katsabanis, P.D. (eds.). Balkema, Rotterdam. pp. 247-252.
DAHLHIELM, S. 1996. Industrial applications of image analysis - The IPACS System. Measurement of Blast Fragmentation: Proceedings of the Fragblast-5 Workshop on Measurement of Blast Fragmentation, Montreal, Quebec, Canada, 23-24 August 1996. Franklin, J.A. and and Katsabanis, P.D. (eds.). Balkema, Rotterdam. pp. 67-71.

Downs, D.C. 1996. Kettunen B E. On-line fragmentation measurement utilizing the CIAS system. Measurement of Blast Fragmentation: Proceedings of the Fragblast-5 Workshop on Measurement of Blast Fragmentation, Montreal, Quebec, Canada, 23-24 August 1996. Franklin, J.A. and Katsabanis, P.D. (eds). Balkema, Rotterdam. pp. 79-82.

Frimpong, M., KABONGo, K., and DAvies, C. 1996. Diggability in a measure of dragline effectiveness and productivity. Proceedings of the 22nd Annual Conference on Explosives and Blast Techniques. International Society of Explosives Engineers. pp. 95-104.

Havermann, T. and Vogt, W. 1996. Tucips - A System for the estimation of fragmentation after production blasts. Measurement of Blast Fragmentation: Proceedings of the Fragblast-5 Workshop on Measurement of Blast Fragmentation, Montreal, Quebec, Canada, 23-24 August 1996. Franklin, J.A. and Katsabanis, P.D. (eds). Balkema, Rotterdam. pp. 59-65.

Kemeny, J.M. 1994. Practical technique for determining the size distribution of blasted benches waste dump and heap leach sites. Mining Engineering, vol. 46, no. 11. pp. 1281-1284.

KLEINE, T.H. 1996. Cameron A R. blast fragmentation measurement using Goldsize. Measurement of Blast Fragmentation: Proceedings of the Fragblast-5 Workshop on Measurement of Blast Fragmentation, Montreal, Quebec, Canada, 23-24 August 1996. Franklin, J.A. and Katsabanis, P.D. (eds). Balkema, Rotterdam. pp. 83-89.

Maerz, N.H., Palangio, T.C., and Franklin, J.A. 1996. The Wipfrag image based granulometry system. Measurement of Blast Fragmentation: Proceedings of the Fragblast-5 Workshop on Measurement of Blast Fragmentation, Montreal, Quebec, Canada, 23-24 August 1996. Franklin, J.A. and Katsabanis P.D. (eds). Balkema, Rotterdam. pp. 91-98.

Michaud, P.R. and BLANCHET, J.Y. 1996. Establishing a quantitative relation between post blast fragmentation and mine productivity: a case study. Measurement of Blast Fragmentation: Proceedings of the 5th International Symposium on Rock Fragmentation by Blast, Montreal, Quebec, Canada, 23-24 August 1996. Franklin, J.A. and Katsabanis, P.D. (eds.). Balkema, Rotterdam. pp. 386-396.

Molotilov, S.G., Cheskidov, V.I., NoRRi, V.K., BotvinniK, A.A., and. IL'BUl'din, D. 2010. Methodical principles for planning the mining and loading equipment capacity for open cast mining with the use of dumpers, Part III: Service capacity determination. Journal of Mining Science, vol. 46, no. 1. pp 38-49.

NieLSEN, K. and KRISTIANSEN, J. 1996. Blast-crushing-grinding optimization of an integrated comminution system. Proceedings of the 5th International Symposium on Rock Fragmentation by Blast. Mohanty, B. (ed.). Balkema, Rotterdam. pp. 269-278

Osanloo, M. and Некмат, A. 2005. Prediction of shovel productivity in the GolE-Gohar mine. Journal of Mining Science, vol. 41, no 2. pp. 177-184.

Raina, A.K., Choudhury, P.B., Ramulu, M., Chrakraborty, A.K., and DudhanKar, A.S. 2002. Fragalyst - An indigenous digital image analysis system for fragment size measurement in mines. Journal of the Geological Society of India, vol. 59. pp. 561-569.

Schleifer, J. and Tessier, B. 1996. Fragscan, a. tool to measure fragmentation of blasted rock. Measurement of Blast Fragmentation: Proceedings of the Fragblast-5 Workshop on Measurement of Blast Fragmentation, Montreal, Quebec, Canada, 23-24 August 1996. Franklin, J.A. and Katsabanis, P.D. (eds.). pp. 73-78.

Tunstall, A.M. and BEARMAn, R.A. 1997. Influence of fragmentation on crushing performance. Mining Engineering, vol. 49. pp. 65-70.

Tosun, A., KonaK, G., KaraKus, D., and OnUR, A.H. 2012. Determination of loader efficiency with hydraulic pressure values. Proceedings of the International Multidisciplinary Scientific Geoconference. Curran Associates. pp. 531-538.

Tosun, A., KonAK, G., Öngen, T., and OnUR, A.H. 2015. Patlatma sonucu olusan yıgının boyut dagilımının belirlenmesinin arastırılması, 7. Ulusal Kırmatas Sempozyumu (National Kırmatas Symposium).

Workman, L. and Eloranta, J. 2004. The effects of blast on crushing and grinding efficiency and energy consumption. Proceedings of the ISEE 29th Annual Conference on Explosives and Blasting Technique, vol. I. International Society of Explosives Engineers, Cleveland, $\mathrm{OH}$. pp. 131-140. 